Please do not remove this page

RMIT

UNIVERSITY

\title{
Mediating corporeality: Re-interpretations at the art/science interface
}

Adams, Patricia

https://researchrepository.rmit.edu.au/esploro/outputs/9921858465401341/filesAndLinks?institution=61RMIT_INST\&index=null

Adams, P. (2012). Mediating corporeality: Re-interpretations at the art/science interface. Somatechnics, 2(2), 284-304. https://doi.org/10.3366/soma.2012.0062

Document Version: Published Version

Published Version: https://doi.org/10.3366/soma.2012.0062

Repository homepage: https://researchrepository.rmit.edu.au

(c) Edinburgh University Press

Downloaded On 2023/04/26 17:21:46 +1000

Please do not remove this page 
Thank you for downloading this document from the RMIT Research Repository.

The RMIT Research Repository is an open access database showcasing the research outputs of RMIT University researchers.

RMIT Research Repository: http://researchbank.rmit.edu.au/

\section{Citation:}

Adams, P 2012, 'Mediating corporeality: re-interpretations at the art/science interface', Somatechnics, vol. 2, no. 2, pp. 284-304.

See this record in the RMIT Research Repository at: http://researchbank.rmit.edu.au/view/rmit:16819

Version: Published Version

Copyright Statement: (c) Edinburgh University Press

Link to Published Version:

http://www.euppublishing.com/doi/abs/10.3366/soma.2012.0062

\section{PLEASE DO NOT REMOVE THIS PAGE}




\title{
Mediating Corporeality: Re-Interpretations at the Art/Science Interface
}

\author{
Patricia Adams
}

\section{Introduction}

This article will investigate evolving methodologies in the burgeoning field of art/science collaborations and the shifting relationship between artistic practice and anatomical representations. Interwoven throughout the text are examples from my collaborative art/science projects machina carnis $^{1}$ and $H O S T$, $^{2}$ two projects that demonstrate theoretical and practical rationale at the art/science interface. Machina carnis was an art/science collaborative project where I assumed a self-reflexive, first-person methodology in the dual roles of a 'human guinea pig' and researcher to experiment on adult stem cells taken from my blood. The data from these experiments was then reinterpteted and incorporated into the machina carnis interactive artwork. The artwork HOST was an initial response to my experiences during a residency with the Visual and Sensory Neuroscience group. ${ }^{3}$ Here, the European honeybee's brain, which is small in relation to the size of the bee and the complexity of its behaviours, forms an ideal platform for fruitful experimental research into levels of sentience and consciousness. In the research environment I was surrounded by honeybees, and HOST reflects on the emotional and theoretical implications of my inter-species proximity to these 'non-human others'. Further discussions on art/science practice and its relationship to corporeal representations include examples from selected historical precedents, with a focus on cellular organisms, entomology and European honeybee research. Enquiries into

Somatechnics 2.2 (2012): 284-304

DOI: $10.3366 /$ soma.2012.0062

(C) Edinburgh University Press

www.eupjournals.com/soma 


\section{Mediating Corporeality}

constructs of corporeality incorporating living systems, inter-species proximity and 'non-human others' are expanded upon by exploring their relationships with media technologies, autopoiesis, and recent theories of evolution.

\section{The machina carnis Project}

Beginning with a description of the origins, both scientific and artistic, of the machina carnis project, I explain why I considered my choice of a first-person research methodology so important, even though it complicated the ethical clearance process. An explanation of the machina carnis project's pioneering scientific procedures outlines how some of my pluripotent adult stem cells were changed into beating cardiac cells in the laboratory, providing digital videomicrograph image data to creatively reinterpret in the machina carnis interactive installation.

The machina carnis project was developed in response to the groundbreaking scientific discovery that adult stem cells are capable of 'changing their fates' ${ }^{4}$ and becoming other types of cells.

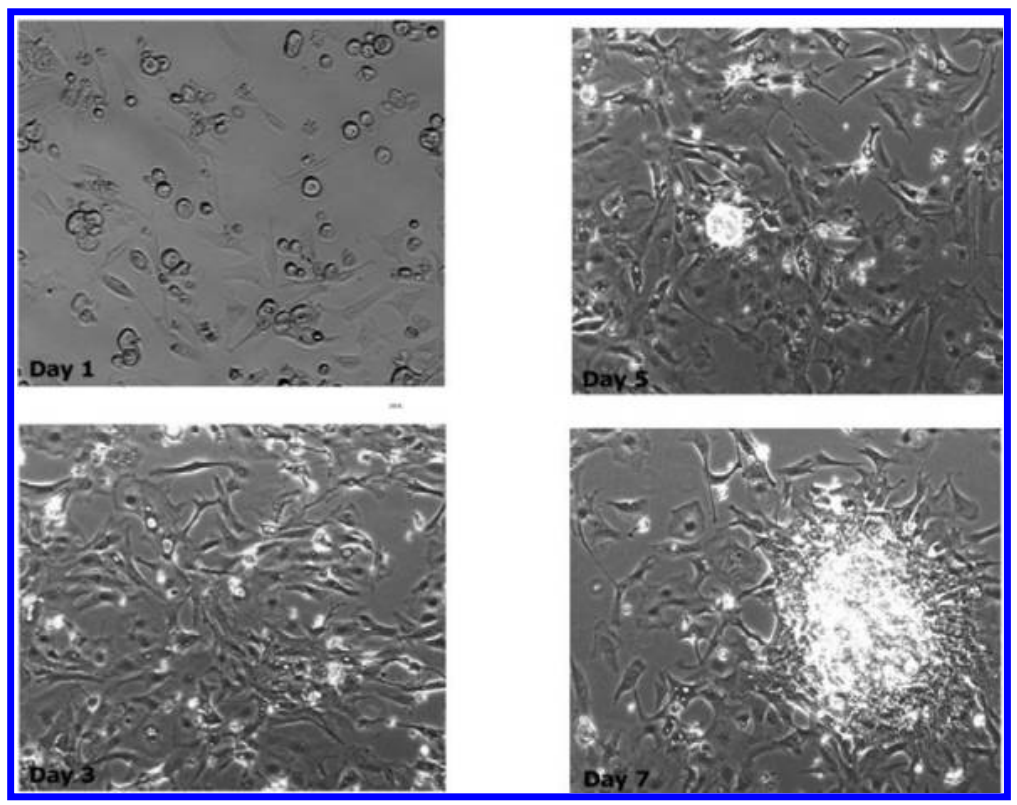

Fig. 1. Digital videomicrograph still images of Trish Adams' adult stem cells in culture changing their fates to become cardiac cells over 7 days.

(Source: Dr V. Nurcombe.) 
This landmark breakthrough in adult stem cell research was reviewed in the December 1999 issue of the journal Science, which described it as the 'scientific discovery of the year' (Vogel 1999: 2238-9). The discovery of the pluripotent ${ }^{5}$ characteristics of some adult stem cells has overturned the prevailing orthodoxy that - once adult - the destiny of a stem cell is fixed and cannot be changed. The ability to chemically modify the development of adult stem cells has the potential to enable doctors and scientists to avoid the ethically controversial use of embryonic stem cells in medical treatments and scientific experiments. Also, significantly, adult stem cells harvested from a patient's own body and then cultured and returned to their body to repair tissue or organ damage, are not rejected by the individual's immune system. Whilst the wide ranging medical implications of adult stem cell technologies are of major importance, from an artistic perspective, the possibility of 'growing' human organs is both confronting and thought-provoking in relation to future concepts of 'corporeality' and the 'self'. The machina carnis project aimed to probe the possible consequences of this groundbreaking development in biomedical science and query their potential repercussions.

In order to foster empathy between the installation participants and the machina carnis project I decided to experiment on my own cells. From a biological standpoint, artwork-participant's cells have the same physiological responses as my cells. Therefore, when I included the digital videomicrograph image data of these human cells in the artwork, I was stimulating emotional transference and personal identification on the part of individual installation participants. Proposing to use unscreened human material created problems when applying for University ethical clearance for the project. The delays in awarding ethical clearance that arose were partly due to concerns about the risk of infection when my unscreened cells were put in University incubators and equipment; and partly the result of issues relating to donor permission and the use of human tissue. ${ }^{6}$ I was committed to using a project model that would create participant emotional identification, so I was determined to find a way to satisfy the ethics requirements. The solution was provided by my scientific collaborator, Dr Victor Nurcombe, ${ }^{7}$ who suggested that we could use adult stem cells from my blood rather than from my epidermis. This shift in the source site for the experimental material meant that I was able to satisfy the University ethics committee requirements by having a sample of my blood taken by a doctor on campus at the School of Human Movement, where the necessary ethical protocols were already in place for the regular collection of athletes' blood samples for 


\section{Mediating Corporeality}

research purposes. After almost a year, the machina carnis project was awarded University ethical clearance and the scientific experimental processes began with the separation of the adult stem cells from my blood sample in the laboratory at the School of Biomedical Sciences. ${ }^{8}$ After three days, we added Dr Nurcombe's patented growth mix to change my adult stem cells into cardiac cells. This mix was composed of the drug 5'AZT and a mixture of cardiac differentiating factors, which have been shown by others in the field to push many cells into cardiac-like fates. The drug is very good at 'switching on' the genes which make the proteins characteristic of heart tissue. The proprietary ingredient was a species of a biologically active sugar that crosslinks active ingredients together into complexes. Heart cells specialise in the cardiac-specific proteins which have contractile (beating) qualities - these are things like cardiac-specific actin, myosin, troponin - as well as the ion channels (cell surface gates) which start off the beating cycle. Finding these proteins would be essential evidence that we had turned naive adult stem cells into cardiac cells.

The machina carnis project posed the question: 'What will occur if a visual artist engages with biomedical engineering as a first-person researcher?' Although unconventional, scientific precedents do exist for first-person scientific research; most recently that of the Australian Nobel Laureate Professor Barry Marshall. ${ }^{9}$ A first-person participatory methodology was central to my exploration of what constitutes 'anatomy' and 'corporeality' when contemporary biotechnology, neuroscience and virtual systems are rapidly changing the ways we see ourselves and actively remodelling the human body. Adopting an immersive strategy of participatory engagement in the role of artist/ researcher has allowed me to "probe the technology whilst existing in the new contexts created by it' (Wilson 1991: 433). In other words, when cellular material from my body became the site for cutting edge, technological biomedical experimental research I was able to complicate the so-called 'Cartesian dualism' of the 'disembodied eye' (Jay 1993: 81) by immersing myself in the entire process in the roles of 'human guinea pig' and artist/researcher. Dr Nurcombe described my immersion in the whole project as follows: 'You have entered into the heart of a research project as a core participant. You were at once subject and object, forced to be objective about your very "ground state" - your own material...' (Nurcombe 2005). This immersive methodology did not emulate the so-called objective research processes that are identified with established scientific practice, and throughout the project I acknowledged my personal involvement and perspective. 


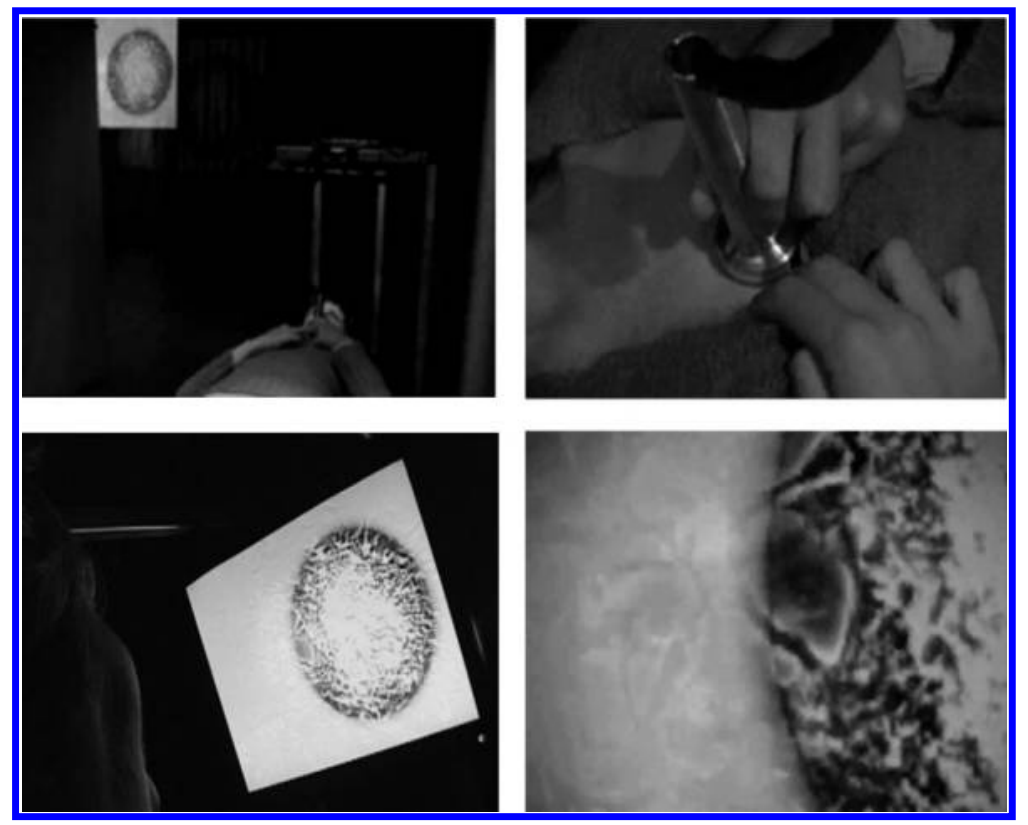

Fig. 2. Images of a participant engaging with the machina carnis interactive installation. The participant is situating the modified stethoscope over her heart and listening to her heartbeats. She is also looking up at a monitor screen showing a loop of digital videomicrograph micrograph images of the stem cells beating in time with her heartbeats. (Source: Ben Wickes.)

The research, immersive, scientific methodologies are mirrored in the installation machina carnis though the use of interactive digital technologies that promoted viewer engagement and sensory immersion. Machina carnis was programmed to respond to one participant at a time, who lay on a couch beneath a computer monitor, encapsulated in a proscribed relationship with the installation to experience an intimate, personal interaction. In order to bring the installation to life $\mathrm{s} / \mathrm{he}$ took the specially modified stethoscope and placed it on the bare skin over her/his heart. When the participant located their heart in this way the sound of their heartbeats resonated around the gallery. At the same time the programmed installation technology responded by synchronising the 'beating' of the time-lapse digital videomicrograph cardiac cellular image data with the individual participant's heart rate. This cardiac cellular digital image data was visible on the monitor above the participant. In addition, an appropriately situated webcam digitally captured the participant's facial image and overlaid it indistinctly in 


\section{Mediating Corporeality}

the cellular image frame visible on the monitor. This was intended to increase the sense of personal engagement experienced by the participant. The interactive digital technologies were integrated discreetly into the machina carnis installation. This facilitated userfriendly access to the artwork so that there was no complex digital interface to distract participants from the phenomenological impact of the human cellular digital image data or the emotive responses evoked by the sound of their own heart beats. In this embodied structural relationship the viewer became a network participant who is receptive to the multi-sensory impact of the artwork environment.

\section{Artists and Anatomy}

Following the introduction of the machina carnis rationale and project stages I will now contextualise contemporary art/science corporeal interventions - such as machina carnis - in their historical context and expand upon the field of art/science interventions as a whole, bearing in mind that, to some readers, this may be familiar ground.

Artistic engagements with the human body have ranged from religious iconography, portraiture and medical imaging through to present-day techniques of photography and digital imaging technologies. Historical records show that, from the fifteenth century to the nineteenth century, artists were called upon to provide scientific and medical representations of the body (Stafford 1993). Although some scientists in the past - such as Robert Hooke or Michael Faraday - were competent artists who could illustrate their own research texts (Inwood 2002; Hamilton 2003), anatomical representations provided quite different challenges and requirements. The specialised role of anatomical representations fell to artists, whose skills were required to create the most accurate anatomical images and wax sculptures possible. Initially these works appear to fall into the category of medicine rather than art. However, as the catalogue for the Hayward Gallery exhibition Spectacular Bodies points out, this is a limited classification that ignores the cultural location of the practice of medicine and its related imagery at that time:

The purpose of anatomical images during the period from the Renaissance to the nineteenth century had as much to do with what we would call aesthetics and theology as with the narrower intentions of medical illustrations as now understood.... Rather, the disclosing of the 'divine architecture' that stood at the summit of God's Creation remained the central goal of anatomical representation across at least three centuries. (Kemp and Wallace 2000:11) 
Consequently, the artist's historical role involved both the ability to create realistic anatomical images of the human body and also the capacity to represent the 'essence' of a human being from a religious and aesthetic perspective.

For an increasing number of contemporary artists the art/science interface provides a stimulating platform from which to interrogate the implications of a wide range of social, ethical and conceptual issues. The Australian bio artist Stelarc represents a high-profile example of one such artist. His pioneering biotechnical critiques and performances were followed by a project at SymbioticA, the designated art/science centre at the University of Western Australia. ${ }^{10}$ Here, the project Extra Ear probed the anatomical status of the human body in relation to the potentials to grow organs - in this case, a quarter-size ear cultured from screened human cells. A further replica of the tiny ear, which made no pretence to carry out the functions of a real ear, was later grafted onto Stelarc's arm. ${ }^{11}$ Similarly, the French duo Art Orienté Objet collaborated with an American skin production laboratory for their artwork cultures de peaux d'artistes. This ethic mirrors my own outlook on biotech experiments where I experiment on my own human material rather than that of laboratory animals - a rationale that personalises artistic engagement in scientific processes.

The emergent use of the body as a site from which to critique developments in biotechnology has added to the tradition of artists making use of their own bodies as a source or resource for art-making. Whether employed as a subject, muse or in a performative context, the human body is charged with significance. In the contemporary context, the carnal art of Orlan queries the status of the corporeal self when she transforms her appearance by undergoing plastic surgery. This surgery is carried out to follow Orlan's artistic design, rather than to enhance beauty or to improve a medical condition. ${ }^{12}$ Artist Justine Cooper subjected herself to an MRI scan to obtain source material for her video Rapt which explored her body from within. ${ }^{13}$ The fate of the organic body was interrogated by the artist Melinda Rackham in her Internet-based artwork Carrier, which movingly humanised her encounter with the Hepatitis C virus. ${ }^{14}$

Some bio artists, such as Edouardo Kac, have experimented on non-human anatomies, adopting the scientific trope of animal experimentation. Kac is perhaps best known for his genetic modification of a rabbit named Alba that caused the rabbit to glow green in fluorescent light and become a 'bioluminescent bunny'. Kac states that he appropriates scientific techniques to create transgenic 


\section{Mediating Corporeality}

artworks that are intended to raise uncomfortable issues related to biotechnology (Eskin 2001). Certainly a debate arose at the time of Kac's experiments - and still continues - about whether Kac's treatment of Alba was cruel. The controversy surrounds the apparent outcome that, as the result of Kac's transgenic interventions, Alba was rejected by her peers and consigned to the realm of 'other', unable to live with her own species.

\section{Art/Science Collaborations}

After the preceding overview of artists' relationships to anatomy, this section discusses the changing parameters of contemporary art/ science collaborations and presents the argument that meaningful art/science collaborations actually create 'something quite other', which exists beyond the parameters of recognised scientific research processes. I introduce my use of the term 'hybridity' to describe this 'otherness' in the art/science collaborative context and demonstrate its application within the framework of meaningful art/science interdisciplinary explorations.

Two fundamental questions relating to the field of art/science collaborations are: 'Can the customarily divergent disciplines of art and science create fruitful collaborative opportunities for artists to interrogate science?' and 'Is artistic involvement with ground-breaking science actually destined to be quite limited?' In his assessment of the extent to which artist-researchers might contribute to techno-scientific debates, art/science researcher Stephen Wilson pointed out that: 'scientists and technology researchers who have devoted their entire professional lives to educating themselves about topics being investigated might be sceptical [... Can] artists learn enough to engage in research at a non-dilettante level?' (1996: 3). Rather than

a collaborative interdisciplinary endeavour, Wilson appears to be referring to an art/science model where established scientific practice and protocols remain in place and to which both artist and scientist adhere. The introduction of a new model of art/ science collaboration - with its own parameters, protocols and methodologies - can overcome this scientific disciplinary hegemony and bring about the introduction of relevant innovative critiques and assessments. If both the 'art' and the 'science' play their part in generating a collaborative project 'whole', an innovative art/science collaborative research model can be developed that builds upon potential investigations and knowledge bases from both these respective disciplines. Meaningful art/science collaborative research 
models focus on interdisciplinary projects that foster spaces for exploratory processes and outcomes. During the mutual, collaborative interchange between the artist and the scientist, spaces for innovation and experimentation occur. In the statement below, Dr Nurcombe explains his views on a broader based art/science collaborative rationale:

I don't see the collaboration between you and I as anything like as quotidian as 'research at a non-dilettante level'. It could only really be considered as 'research' as I understand it, at a much more esoteric level; I would have thought we set out to do something quite 'other', something more open-ended. Research with other scientists is usually extremely focused and conducted within tight parameters; it's not about possibilities so much as progressively excluding as many possibilities as possible. Our work was conducted much more in the spirit of 'what if'? (Nurcombe 2005)

Although my practical engagement with the scientific experimental domain is contingent on the necessary laboratory disciplinary rigour, my observations and data interpretations have deliberately maintained the acknowledged art/science focus that Dr Nurcombe has described as 'something quite other'.

The term 'hybrid' elucidates both the exploratory methodologies necessary to create art/science collaborations and the fruitful, innovative outcomes generated by them at the art/science interface. 'Hybrid', in this context, encapsulates the amalgamation of art/science collaborative experimental research parameters. As Professor of Digital Media Art Joel Slayton suggests, constructive links occur when artistic collaborations expand upon aspects of research in unexpected ways: 'although art and science share many characteristics, a special role for the arts exists in the evolution and deployment of technology - the implication being that by operating outside the conventions of traditional practice, unique and significant research enterprises can and will unfold' (Slayton 2001: xxi). Consequently, in art/science collaborations such as my own, spaces for artists arise within the sciences when the exploratory collaborative methodologies are adaptable enough to be opened up and create a different type of research dynamic at the art/science interface. Hybrid entities are generated when the disciplines of art and science merge their divergent perspectives and are not aiming to mimic the so-called objectivity of 'hard' scientific research processes and outcomes. Indeed, historically, this open-ended approach recalls the exploratory research of the seventeenth and eighteenth century 


\section{Mediating Corporeality}

'natural philosophers', who met in groups to explore and discuss intriguing phenomena in their environment (Uglow 2002). The natural philosophers' approach flourished prior to the nineteenthcentury separation of art and science into discrete disciplines, when socalled scientific rigour emerged. Subsequently, art and science continued to diverge and the term 'scientist' was introduced to describe the practitioners of the newly established discipline of science. The spirit of 'what if', epitomised by the natural philosophical processes of enquiry, was superseded by the now familiar analytical strictures of contemporary scientific practice. In contrast, it is suggested here that productive, contemporary art/ science collaborations can only be developed in the spirit of 'what if?'

\section{Mediation and Technologies}

Beginning with an overview of experiences and observations of technologies in scientific research laboratories, this section continues by introducing the historical relationship between scientific research and developing technologies. Theories of observer relativity are discussed in relation to developments in both historical and contemporary scientific technologies and methodologies. The discussion concludes with an exploration of artistic reinterpretations of scientific data and the creative mediations that an artist might make between this data and an artwork audience.

During my art/science projects, I became aware of the technological mediations involved in scientific processes. Previously held concepts are regularly updated and modified as the result of new findings produced with the aid of the latest technological devices. ${ }^{15}$ Historically, scientific research has been driven by the available tools of its time. For example, the arrival of electric power fuelled the invention of all manner of machines and devices that scientists hoped would lead to a better understanding of the human body through direct analysis of its electrochemical reactions. Within this field of galvanics - famously pioneered by Carlos Matteucchi's experiments with the rheoscopic frog's leg in $1838^{16}$ - machines such as the kymograph measured and recorded electrical energy from chemical reactions taking place within the cell. During the 1880s, the scientist and chronophotographer Etienne-Jules Marey employed the myograph to make original visual records of insect flight. Marey went on to develop the field known as 'animated photography' to record and explore movement in what was then unparalleled detail (Braun 1992; Parikka 2010: 12-14). This early research provides a historical counterpoint to my own engagement 
with the fast-capture cameras to record intricate details of honey-bee flight.

In addition to the experiments with fast-capture cameras and time-lapse digital videomicroscopy I have 'driven' a JSM Scanning Electron microscope during my research projects. Of particular consideration in electron microscopy is the implication that - in the otherwise invisible layers of nano-microscopy - the technologies of seeing become mechanisms for believing, since the observer is essentially dependent on a prosthetic device. In this instance, the observer is required to trust in the veracity of the machine, with all its potential epistemic and technological limitations, which prompts speculation about the status of scientific imaging in the documentary context. Scanning, tunnelling microscopes are in fact referred to as 'endo technology' and the science of endophysics addresses such issues as observer-relativity, representation, and non-locality, exploring what a system looks like when the observer becomes part of the system (Weibel 1992). The relationship between machine and observer is particularly problematic if, in the words of postmodern literary critic, Professor N. Katherine Hayles, 'the observer...does not so much discern pre-existing systems as create them through the very act of observation' (Hayles 1999: 2). The landmark research into autopoiesis and cognition by biologists Humberto Maturana and Francisco Varela also highlights the way in which an observer is inevitably drawn into the system s/he seeks to observe (Maturana and Varela 1980).

How an artist might re-interpret and recontextualise scientific research data has been of primary concern during my art/science projects. Visual scientific data can be very powerful and I wanted to retain its impact. However, appropriation of data is not my particular artistic aesthetic and my creative processes have involved disrupting the perceptual proscriptions inherent in scientific data in order to recontextualise it in an artistic context. Consequently, my artistic methodologies have often involved the use of digital image modification and/or the creation of technically programmed participant interactivity that acknowledges observer engagement in the final 'reading' of the data and the 'completion' of the artwork. Academic and artist Anna Munster suggests that digitality provides a set of lived circumstances in which our senses encroach upon us in a different way (Munster 2003) and this premise is frequently incorporated in my artworks. For example, the machina carnis artwork concentrates on the impact of the human cellular digital image data on installation participants, whilst HOST draws artwork viewers into the intersecting domains of interspecies proximity, 


\section{Mediating Corporeality}

recorded in great detail by the digital, fast-capture cameras used for honeybee research. In both artworks, digital image research data is recontextualised as a site for identification and empathy for the viewer/participant.

\section{Corporeality and 'Humanness'}

This paper now turns to a consideration of what might constitute 'humanness' in the context of the complexities arising out of detailed microscopic observations of cellular behaviours and developments in contemporary biotechnology. When querying and exploring the status of cells as living organisms, the theory of autopoiesis and discussions on definitions of 'mind' and 'brain' are particularly cogent. The machina carnis installation is reintroduced as an example of the impact that these queries about cellular sentience had upon the reinterpretations of scientific data used to create its interactive installation structure.

Recent developments in cutting-edge biomedical techniques that can modify human anatomy have stimulated the essential enquiry: "What constitutes "humanness" when both contemporary biotechnology and digital systems are rapidly changing the ways we see ourselves and actively remodelling the human body?' Technical tools such as time-lapse digital videomicrography have enabled highly detailed observations of adult stem cell behaviours and the recording of their development into cardiac cells. The 'changing fate' of my adult stem cells into beating cardiac cells clearly involved a chemical scientific process that modified their anatomical structure; however, Dr Nurcombe and myself did not remain clinically detached during this research process. For us, the sentient responses of the cells evoked a 'quasi-human-like' status and, as a result of that, we both anthropomorphised the behaviours of these living organisms. As Dr Nurcombe and I observed the adult stem cells react as living organisms to the various experimental processes in their laboratory culture dishes, we referred to their 'likes' and 'dislikes' in the same way we would speak about the actions of fellow human-beings. Furthermore, I found the experience of holding containers of my own cells for experimental purposes both unique and emotionally significant. The apparent sentience of these microscopic organisms, even when they had been removed from my body, impacted upon me. In the Petri dish, for example, the cardiac cells were able to seek each other out, interdigitate and synchronise their beating. Although I understood that the cellular characteristics could be scientifically explained as programmed behaviour and a response to being exposed 
to the unique experimental chemical mix, I still felt amazed and intrigued by them. As the result of my cellular behavioural observations, my research has focused on explorations into the nature of 'consciousness' and the characteristics of 'life' at a microscopic level. Whilst human in origin, the cells functioned as independent anatomical entities outside my body, their organic structures and processes in full view in a Petri dish through the microscope. When the cardiac cells followed specific behaviours and patterns of interaction, they gave every appearance of some basic form of consciousness as they responded to each other in complex interrelationships. Media theorist Eugene Thacker elaborates on cellular reactions that provide examples of a network of many intersecting units, each aware of the other, which are described as a technoscience of living systems that marks a shift from a linear science of 'life' (Thacker 2004). The status of living organisms and the behaviours of inter-related biological systems have impacted on the machina carnis artwork; where the installation structure stressed the corporeal engagement of participants through their immersion in the interactive artwork 'system of being'.

Self-reflexive characteristics of anatomical systems are expanded upon in Maturana and Varela's theory of autopoiesis (Maturana and Varela 1980). 'Simple' cellular living systems provided Maturana and Varela with appropriate models for investigating 'autopoietic networks'. Autopoiesis is not a property of living systems; rather it represents an actual manner of being since, in molecular space, behaviours occur in relation to whatever environmental stimuli are present. Maturana and Varela's 'Santiago Theory' of cognition queried the status of 'living/non-living' and 'consciousness' and is particularly relevant to my own observations of cellular life. Physicist and systems theorist Fritjof Capra expands upon the Santiago Theory in relation to the behaviour of microscopic organisms:

The brain is not necessary for mind to exist. A bacterium, or a plant, has no brain but has a mind. The simplest organisms are capable of perception and thus of cognition. They do not see, but nevertheless perceive changes in their environment - differences between light and shadow, hot and cold, higher and lower concentrations of some chemical etc. (Capra 1996: 170)

The machina carnis project provides examples of the way I have drawn inspiration from my observations of cellular life, since it was structured to resemble a self-reflexive autopoietic organism. The artwork system was created through the discrete use of programmed computer 


\section{Mediating Corporeality}

technologies to mirror the reflexivity of biomedical processes. The responsive machina carnis 'organism' was brought to life in the gallery by each individual viewer, whose participation rendered them an integral part of the network itself.

\section{Entities and Environments}

The previous section's query into the status of cells as living organisms prompts an examination of the categories of living beings. An overview of theories relating to posthuman entities contextualises the trajectory of my research into the area of 'non-human actors' such as the honeybee. Theories relating to inter-species proximity are expanded upon and illustrated by my own experiences in the honeybee research facility and my creative rationale for the artwork HOST. To conclude, networks in the computer sciences and the field of environmental theories are considered and discussed in the context of the relationships between corporeality and spatial awareness.

When considering the status of my adult stem cells or my interspecies proximity to the honeybees, one is mindful of the extensive body of research on posthuman entities and actors that are not human. Pioneers in the debates into metaphoric monstrous entities and boundary figures have destabilised and undermined the domination of pure categories such as 'human and non-human' (Lykke and

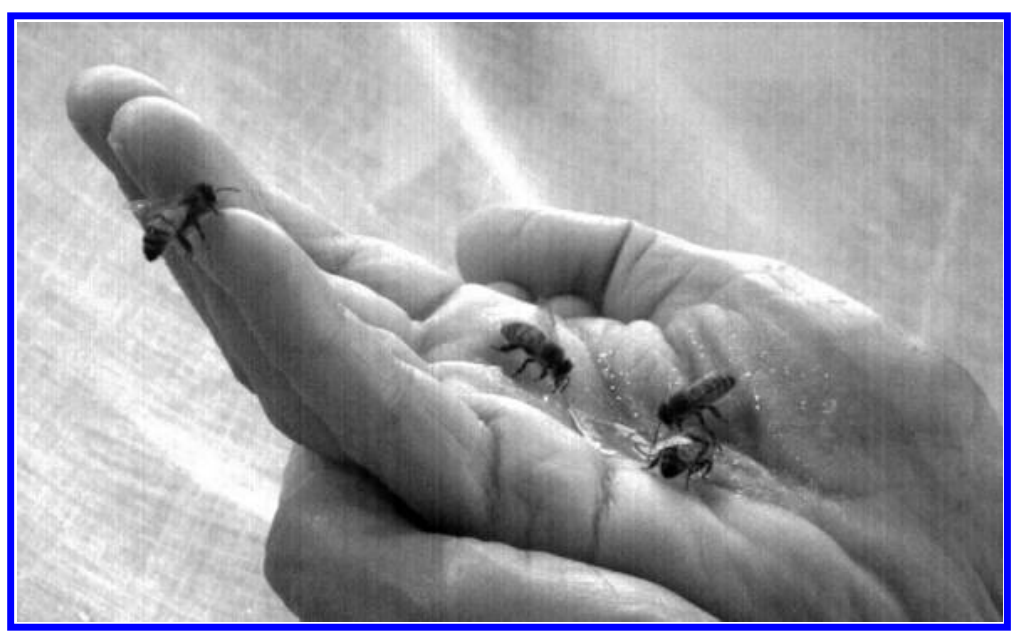

Fig. 3. Still from Trish Adams' video HOST showing bees coming to Trish's hand to feed. (Source: Video Trish Adams; original cinematography, Carla Evangelista and Peter Kraft.) 
Braidotti 1996; Latour 1993; Haraway 1991). Consciousness Professor Emerita, Donna Haraway is also a trained biologist and she has selected stem cells as a symbol for pathways, connections and articulated systems. Haraway uses technoscience as 'materialized semiosis' (Haraway 1997: 130) to explore the depths and multiplicity of relationality that distinguishes her critical practice, where "not all the actors have language, but they nevertheless can be caught up in signification' (Sofoulis 2003: 87). When describing her on-going entanglements of species Haraway states: '[f] or many years I have written from the belly of powerful figures such as cyborgs, monkeys and apes, oncomice, and, more recently, dogs', and she regards these entities as the 'principle others to man' (Haraway 2008: 4). Media theorist Jussi Parikka discusses the history of etymological studies and the contemporary relevance of pioneering ethological research in probing inter-species links. He outlines the possibilities that insects and other nonhuman animals offer for rethinking media and for challenging our views of bodily boundaries in the natural world and artificial mechanical structures (Parikka 2010).

My explorations into characteristics of 'humanness', 'corporeality' and 'consciousness' have involved inter-species proximity and the status of living entities through both adult stem cell experiments and honeybee research. My aim, when I became visiting artist with Professor Mandyam Srinivasan and the Visual and Sensory Neuroscience group, was to observe and participate in European honeybee experiments that would shed light on my understanding of cellular consciousness. The Visual and Sensory Neuroscience group carry out their research in the largest indoor bee facility in Australia where the bees fly around freely from hives to experimental sites and, to my surprise, protective clothing is not routinely worn. After a lifetime of avoiding bees, I initially found the experience of being surrounded by bees in an enclosed environment without any protective clothing quite challenging. Gradually I became accustomed to entering the designated facility full of honeybees. As I watched the bees going about their tasks I found that they did not harm me if I did not disrupt them. In this environment the honeybees and human beings co-existed side by side in their parallel operational spheres. Honeybees and humans were functioning independently - but juxtaposed - within the same habitat. I found this experience of intersecting domains a very powerful one and my encounters sharing a space with the honeybees inspired my video, HOST. For this artwork, the scientists trained the honeybees to come and feed on sweet liquid on the palm of my hand. We made use of fast capture cameras to record the flights of the 


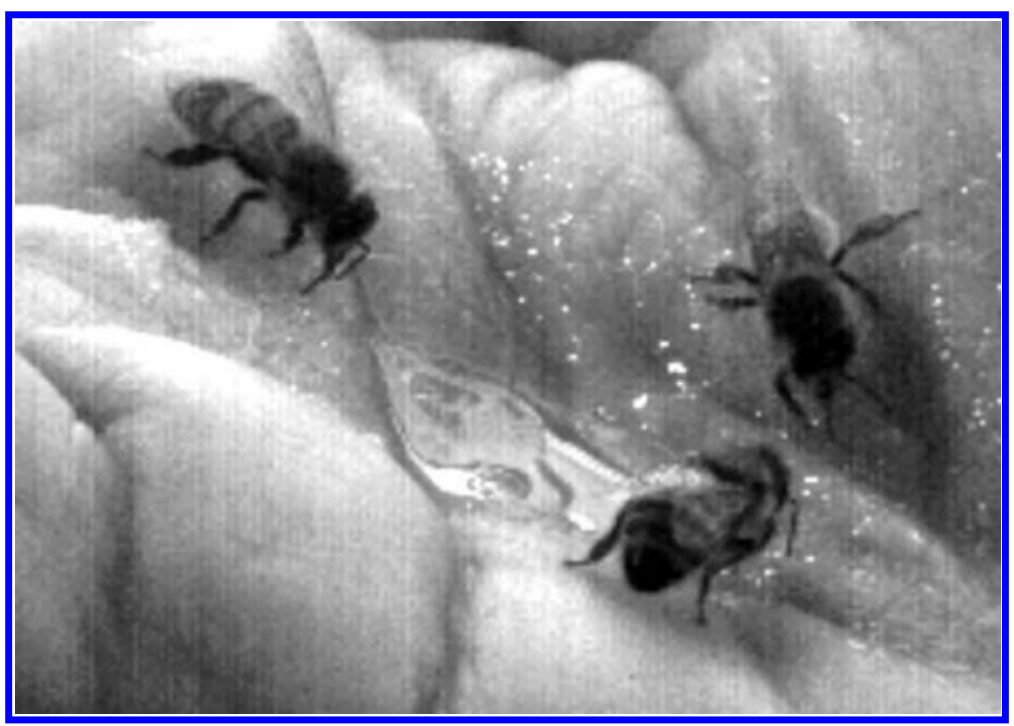

Fig. 4. Close-up still from Trish Adams' video HOST showing the vulnerable bees crawling on Trish's hand. (Source: Video Trish Adams; original cinematography, Carla Evangelista and Peter Kraft.)

honeybees at 250 frames per second, resulting in slow-motion digital visual data. When the bees landed on my hand to eat they entered into an unusual symbiosis with a human being - a poignant example of interspecies contiguity. In close-up shots in HOST, my hand appears disproportionately immense in relation to the insects' bodies. Although I remain vulnerable since the bees can sting me at any moment, the bees also appear vulnerable as they stumble over the alien, fleshy terrain of my magnified palm in search of food. This vulnerability mirrors the current world-wide crisis in honeybee populations. Colony collapse disorder is taking its toll of honeybee communities and, worse case scenario, threatening to wipe out the honeybee altogether. Whilst HOST does not make direct reference to this situation it does draw attention to vulnerability in the human and the honeybee, and their closely linked, delicate, ecological connection.

The networks that exist between both human and non-human living entities include areas such as machine intelligence, cybernetics, biological feedback systems and computer technologies. These fields were investigated in cybernetic and technological experiments during World War II, the post-war Macy conferences and the research of such pioneers as Norbert Weiner ${ }^{17}$ providing widely documented results that form a theoretical framework for contemporary discoveries. For 
example, recent evolutionary research continues to endorse earlier theories relating to biological feedback loops, categories of living systems and adaptive behavioural responses. For contemporary scientists, such as biochemist Nick Lane, disequilibrium and the development of spontaneous networks that are sensitive to their environment are considered to be key factors in the origins of organic development-a dynamic process that has replaced other flat primordial soup concepts of the development of early life. Lane subscribes to the view that rift vents on the ocean floor, discovered in the early 1970s, provided key sites for the thermodynamic chemical reactions required to stimulate life. Both warm and cold vents have been discovered, but through different adaptive processes to each of these environments, the bacteria living near the vents have been able to evolve sufficiently in both these milieu to create 'biospheres' with 'networks of multi-dimensional structural couplings' (Lane 2010: 10-23). In order to leave the vents, the bacteria developed the ability to harness the chemiosmotic processes needed to cultivate the first examples of primitive life. The single-celled cyanobacteria that comprise the so-called 'living rock' or 'stromatolites' visible at Shark Bay, Western Australia, provide present-day remnants of this ancient evolutionary process. ${ }^{18}$

Environmental contexts and affects can be regarded as primary vectors for the creation of entities and their relations both to each other and their surroundings. This inter-relationality has been evident to me when observing the responses of the cardiac cells and during my experiences in an enclosed environment alongside honeybees. Once again I refer to Parikka for examples of the interest that has been developing since the nineteenth century in insect communities, behaviours and social structures and the spatial conditions of variation found in all sentient animals and entities. Natural processes can be said to generate intersections between characteristics of both the natural world and media technologies. In this environmental and affective continuum, honeybees are contextualised in terms of

their capabilities of perceiving and grasping the environmental fluctuations as part of their organisational structures. The hive, then, extends itself as part of the environment through the social probings that individual bees enact where the intelligence of the interaction is not located in any one bee, or even a collective of bees as a stable unit, but in the 'in-between' space of becoming: bees relating to the mattering milieu, which becomes articulated as a continuum to the social behaviour of the insect community. This community is not based on 


\section{Mediating Corporeality}

representational content, then, but on distributed organisation of the society of nonhuman actors. (2010: 129)

Professor Srinivasan and the Visual \& Sensory Neuroscience group's research into the vision, navigation and 'cognition' in insects such as honeybees provides a prime example of the intersections between technology, biology and the behaviours and perceptions of 'actors that are not human', and has extended applications for creating increasingly sophisticated robotic systems.

\section{Conclusion}

The trajectory of the art/science research projects described here has encompassed a range of strategies through which corporeality is mediated. Engagement with cutting edge scientific technologies has stimulated my creation of artworks that have discretely featured the affective qualities of both environments and media technologies. Inserting a personal response into the reinterpretation and recontexualisation of scientific data has involved an acknowledged rejection of so-called scientific objectivity and expanded upon contemporary theories about non-human 'others', 'self' and 'corporeality'. Indeed, the newly discovered pluripotent characteristics of many adult stem cells have opened the door for potentially wide-ranging changes to our anatomical structure - what once appeared immutably 'human' may no longer be so. Expanded expressions and representations of corporeality embrace open-ended and intersecting territories that accommodate malleable, hybrid identities and investigate the cognitive and sentient behaviours observed in cellular life. Considerations of inter-relational pathways and connections have encouraged me to move beyond customary categorisations and environments to traverse permeable membranes between both cellular and inter-species domains. The machina carnis and HOST projects demonstrate slippage between contemporary biomedical cellular research and current enquiries into non-human 'others' such as honeybees. Insect responses and their suggested bodily perceptions of the world around them illustrate tensions between pattern and purpose that are relevant to on-going research into media technologies and networked environmental relationships. Paradigms for meaningful collaborative intersections between art and science that engender hybridity have been outlined and situated within the contemporary research context. These developing models of fruitful transdisciplinary art/science collaborative projects provide an 
on-going research platform for interrogations into biomedical and anatomical shifts in constructs of corporeality at the beginning of the twenty-first century and beyond.

\section{Acknowledgements}

Dr Victor Nurcombe was the machina carnis adult stem cell experimental scientific director and advisor. He is now a principle researcher at the IMCB, Singapore.

Extensive in-kind support and laboratory facilities for the machina carnis project were provided by the School of Biomedical Sciences, The University of Queensland, Brisbane, Australia.

The Brisbane Powerhouse provided a venue and in-kind support for the machina carnis installation.

Trish Adams' doctoral research was sponsored by an Australian Postgraduate Award through Griffith University, Brisbane, Australia.

Professor Mandyam Srinivasan and the Visual and Sensory Neuroscience group host Trish Adams as a visiting artist in residence at the Queensland Brain Institute, The University of Queensland.

The original cinematography for HOST was recorded by Carla Evangelista and Peter Kraft.

Some of the subject matter under discussion in this paper has been presented by the author at Conferences, Symposia and included in previous scholarly publications.

\section{Notes}

1. Machina carnis: visual documentation and additional information is available on Trish Adams' website http://www.trishadams.tv and http://vimeo.com/channels/ $115324 \# 12730173$

2. The video HOST: http://vimeo.com/channels/115324\#12708853

3. The home page of Professor Mandyam Srinivasan and the Visual and Sensory Neuroscience group: http://www.qbi.uq.edu.au/group-leader-srinivasan

4. 'Changing fates' is the term used by biomedical scientists to describe the scientific process of modifying the developmental process of some pluripotent adult stem cells to change them into other types of cells.

5. 'Pluripotent' refers to a cell that is capable of differentiating into other types of cell.

6. The landmark case of Henrietta Lacks created much of the caution now exhibited in the award of ethical clearance. Briefly, in 1951 the cancerous cells of a low income African American woman, Henrietta Lacks, were appropriated without her permission and cultured for supply to scientific laboratories. The culture strain, known as He-La, proliferated world-wide and became so entrenched in the research system that it is suggested that some scientific experimenters even ceased to regard them as of human origin. See: Skloot, Rebecca (2010), The Immortal Life of Henrietta Lacks, New York: Crown Publishing Group for further information. 


\section{Mediating Corporeality}

7. Dr Victor Nurcombe was my scientific collaborator for the machina carnis project. See the Acknowledgements section for further details.

8. The School of Biomedical Sciences, The University of Queensland hosted the machina carnis scientific experiments. See Acknowledgements for further details.

9. Dr Barry Marshall drank bacteria in his efforts to prove that bacteria, not stress, cause stomach ulcers. For more information, see http://www.achievement.org/ autodoc/page/marlbio-1

10. SymbioticA is an artistic laboratory dedicated to the research, learning, critique and hands-on engagement with life sciences: http://www.symbiotica.uwa.edu.au/

11. Further information about the Extra Ear project: http://stelarc.org/?catID=20242

12. Further information about Orlan's carnal art projects: http://www.orlan.net/

13. Video documentation of Rapt: http://www.youtube.com/watch?v=6dIzBwK0xoE

14. Further information on Carrier: http://www.subtle.net/carrier/gallery.html

15. One landmark example of research results that changed a dominant paradigm is Benjamin Libet's discoveries, starting in 1957-1958, on how the human brain produces conscious awareness. Libet discovered that, contrary to the previous view that our reflex actions are immediate, there is actually about a 350-500 millisecond delay before the brain processes a reaction. Libet, Benjamin. (2004) Mind Time: the Temporal Factor in Consciousness, Cambridge, Harvard University Press and also: Neuroscience and Free Will, Referenced $22^{\text {nd }}$ November 2011, http://www. youtube.com/watch?v=IQ4nwTTmcgs

16. For more information, see Salvatore, Emma, A Brief look at ECG Sensor Technology, http://www.mdtmag.com/Articles/2011/08/A-Brief-Look-at-ECG-SensorTechnology/

17. For more information, see Pfohl, Stephen (1997) The Cybernetic Delirium of Norbert Weiner, article a004, http://www.ctheory.net/articles.aspx?id=86

18. For information on the stromatolites of Shark Bay, see: http://www.sharkbay.org/ stromatolites.aspx

\section{References}

Braun, Marta (1992), Picturing Time: The work of Etienne-Jules Marey, Chicago: University of Chicago Press.

Capra, Fritjof (1996), The Web of Life, London: HarperCollins.

Eskin, Blake (2001), 'Building the Bioluminescent Bunny', 10 May 2012, http:// www.ekac.org/artnews2001.html

Hamilton, James (2002), Faraday: The Life, London: HarperCollins.

Haraway, Donna (1991), 'A cyborg manifesto: science, technology, and socialistfeminism in the late twentieth century', in Simians, Cyborgs and Women: The Reinvention of Nature, New York: Routledge, pp.149-81.

Haraway, Donna (1997), Modest_Witness@Second_Millennium.FemaleMan@_Meets_Onco Mouse $\mathrm{Mi}$, London and New York: Routledge.

Haraway, Donna (2008), When Species Meet, Minneapolis: University of Minnesota Press.

Hayles, N. Katherine (1999), How We Became Posthuman: Virtual Bodies in Cybernetics, Literature, and Informatics, Chicago: University of Chicago Press.

Inwood, Stephen (2003), The Man Who Knew Too Much: The Strange and Inventive Life of Robert Hooke 1635-1703, Pan Books: London.

Jay, Martin (1993), Downcast Eyes: The Denigration of Vision in Twentieth Century French Thought, Berkley: University of California Press. 


\section{Somatechnics}

Kemp, Martin and Marina Wallace (2000), Spectacular Bodies, London: Hayward Galleries Publishing.

Lane, Nick (2010), Life Ascending: The Ten Great Inventions of Evolution, London: Profile Books.

Latour, Bruno (1993), We Have Never Been Modern, London: Harvester Wheatsheaf.

Lykke, Nina and Rosi Braidotti (1996), Between Monsters, Goddesses and Cyborgs: Feminist Confrontations with Science, Medicine and Cyberspace, New Jersey: Zed Books.

Maturana, Humbert and Francisco Varela (1980), Autopoiesis and Cognition: The Realisation of the Living, Dordrecht: D. Reidel Publishing Company.

Munster, Anna (2003), 'This fanciful and colourful image: the image of new media within the contemporary art - science nexus', Culture Magazine, 5: e-issue, pp. 1-13, 23, November 2011, http://www.culturemachine.net/index.php/cm/article/view/ $253 / 236$

Nurcombe, Victor (2005), e-interview, in P. Adams, 'The Implications for Artistic Expressions and Representations of Corporeality of the Experimental Techniques of Biomedical Engineering', Doctor of Visual Arts Thesis, Griffith University, appendix v.

Parikka, Jussi (2010), Insect Media, Minneapolis: University of Minnesota Press.

Slayton, Joel (2001), 'Introduction', in Stephen Wilson, Information Arts: Intersections of Art, Science and Technology, Cambridge: MIT Press, pp. ix-xxii.

Sofoulis, Zoe (2002), 'Cyberquake: Haraway's manifesto', in D. Tofts, A. Johnson, and A. Stafford, Cavallaro (eds), Prefiguring Cyberculture: An Intellectual History, Sydney: Power Publications, pp. 84-103.

Stafford, Barbara (1991), Body Criticism: Imaging the Unseen in Enlightenment Art and Medicine, Cambridge: MIT Press.

Thacker, Eugene (2004), 'Networks, swarms, multitudes: part two', ctheory.net, Kroker A.M. and (Eds), pp. 1-15, 23 November 2011, http://www.ctheory.net/ articles.aspx?id $=423$

Uglow, Jenny (2002), The Lunar Men: Five Friends Whose Curiosity Changed the World, London: Faber and Faber.

Vogel, Gretchen (1999), 'Capturing the promise of youth', Science, 286:5448, pp. 2238-9.

Weibel, Peter (1992), 'Endo \& nano - over and beyond the limits of reality', in K. Gerbel and P. Weibel (eds), Die Welt von Innen: Endo und Nano, Austria: Conference Publication, Ars Electronica.

Wilson, Stephen (1991), 'Technological research and development as a source of ideas and inspiration for artists', LEONARDO, 24:4, pp. 433-40.

Wilson, Stephen (1996), 'Art as research', 23 November 2011, http:// userwww.sfsu.edu/ swilson/papers/artist.researcher.html 